\title{
An investigation on possible effect of leaching fractions physiological responses of hot pepper plants to irrigation water salinity
}

\author{
Rangjian Qiu', Chunwei Liu', Fusheng Li ${ }^{2}$ Zhenchang Wang ${ }^{3}$, Zaiqiang Yang ${ }^{1}$ and Ningbo Cui ${ }^{4^{*}}$
}

\begin{abstract}
Background: The modification effect of leaching fraction (LF) on the physiological responses of plants to irrigation water salinity $\left(\mathrm{EC}_{\mathrm{iw}}\right)$ remains unknown. Here, leaf gas exchange, photosynthetic light-response and $\mathrm{CO}_{2}$-response curves, and total carbon $(\mathrm{C})$ and nitrogen $(\mathrm{N})$ accumulation in hot pepper leaves were investigated under three

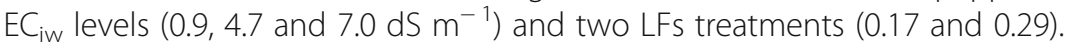

Results: Leaf stomatal conductance was more sensitive to $\mathrm{EC}_{\mathrm{iw}}$ than the net photosynthesis rate, leading to higher intrinsic water use efficiency (WUE) in higher $\mathrm{EC}_{\mathrm{iw}}$, whereas the LF did not affect the intrinsic WUE. Carbon isotope discrimination was inhibited by $\mathrm{EC}_{\mathrm{iw}}$, but was not affected by LF. EC $\mathrm{C}_{\mathrm{iw}}$ reduced the carboxylation efficiency, photosynthetic capacity, photorespiration rate, apparent quantum yield of $\mathrm{CO}_{2}$ and irradiance-saturated rate of gross photosynthesis; however, LF did not influence any of these responses. Total $\mathrm{C}$ and $\mathrm{N}$ accumulation in plants leaves was markedly increased with either decreasing $\mathrm{EC}_{\mathrm{iw}}$ or increasing LF.

Conclusions: The present study shows that higher $\mathrm{EC}_{\mathrm{iw}}$ depressed leaf gas exchange, photosynthesis capacity and total $\mathrm{C}$ and $\mathrm{N}$ accumulation in leaves, but enhanced intrinsic WUE. Somewhat surprisingly, higher LF did not affect the intrinsic WUE but enhanced the total $\mathrm{C}$ and $\mathrm{N}$ accumulation in leaves.

Keywords: Photosynthetic light-response curve, $\mathrm{CO}_{2}$-response curve, $\delta^{15} \mathrm{~N}, \Delta^{13} \mathrm{C}$, Photosynthetic capacity

\section{Background}

In many countries, the shortage of fresh water is a principal factor restricting the development of irrigated agriculture. The use of saline water is a possible alternative to meet the increased water demands for irrigation [1]. A prototypical case is the cultivation of pepper (Capsicum annuum L.), which is now one of the most widely grown crops in the world. In 2016, global pepper production (fresh and dry) from some 4 million ha was estimated at some 39 million tonnes, increasing by some $30 \%$ in the last decade [2]. Increasing demand for pepper is perhaps not surprising for high nutritional value of pepper. However, the total water requirement for pepper cultivation is by no means small ranging from 500 to $900 \mathrm{~mm}$ and up to $1250 \mathrm{~mm}$ in some areas [3]. In arid and semi-arid regions

\footnotetext{
* Correspondence: cuiningbo@scu.edu.cn

${ }^{4}$ State Key Laboratory of Hydraulics and Mountain River Engineering \& College of Water Resource and Hydropower, Sichuan University, Chengdu 610065, China

Full list of author information is available at the end of the article
}

where much of the pepper cultivation occurs, fresh water resources are scarce necessitating the use of recycled (and often saline) water. In some areas, up to $1200-1400 \mathrm{~mm}$ of saline water with salinity levels ranging from 2.2 to $3.7 \mathrm{dS} \mathrm{m}^{-1}$ have been successfully used to meet pepper water requirements [4]. Unsurprisingly, as with many other crops, irrigation with saline water can result in the accumulation of salt in the root zones, leading to the reduction in pepper growth and yield $[5,6]$. Such reduction is the consequence of several physiological responses including lower $\mathrm{CO}_{2}$ uptake, intercellular $\mathrm{CO}_{2}$ concentration, and availability of intercellular $\mathrm{CO}_{2}$ for carboxylation by decreasing stomatal conductance $\left(g_{s}\right)$, as well as the reduction in photosynthesis capacity, photosynthesis rate $\left(P_{n}\right)$, and depression in both the photochemical and Calvin cycle reactions $[7,8]$. To maintain the minimum salinity in the root zones and enhance crop growth, a considerable amount of water is needed to drain salinity when the field is irrigated with saline water [9]. Leaching fraction (LF) is the volume of drainage water passing through the

(c) The Author(s). 2019 Open Access This article is distributed under the terms of the Creative Commons Attribution 4.0 International License (http://creativecommons.org/licenses/by/4.0/), which permits unrestricted use, distribution, and 
root-zones divided by the volume of irrigation water. Crop yield with saline water irrigation depends on plant evapotranspiration as well as soil salinity leaching [10]. Previous studies have focused on the effects of LF on root growth [11], root-zone salinity, evapotranspiration and yield [10, 12-14]. However, little information is available on the physiological response of hot pepper leaves to LF.

Intrinsic water use efficiency (WUE), defined as the ratio of $P_{n}$ to $g_{s}$ at leaf level, can explain instantaneous responses to environmental factors [15]. Intrinsic WUE can be enhanced either by lowering $g_{s}$, or by maintaining or enhancing the $P_{n}[16,17]$. As salinity stress simultaneously decreases $g_{s}$ and $P_{n}$, the intrinsic WUE varies under different salinity levels. Assessing the Brazilian pepper tree (Schinus terebinthifolius Raddi), Ewe and Sternberg (2005) [18] reported that the intrinsic WUE did not statistically differ among their salinity treatments, ranging from 0 to $21.4 \mathrm{dS} \mathrm{m}^{-1}$. Likewise, Yarami and Sepaskhah (2015) [19] noted that the intrinsic WUE of saffron (Crocus sativus) was not affected when irrigation water salinity $\left(E C_{i w}\right)$ was lower than $3.0 \mathrm{dS} \mathrm{m}^{-1}$. However, for some crop species, including water melon (Citrullus lanatus) [20], henna (Lawsonia inermis) [21] and plantain (Plantago coronopus) [22], high salinity improved the intrinsic WUE as the sensitivity of $g_{s}$ to salinity increased relative to $P_{n}$. Further investigation is therefore necessary to assess whether $\mathrm{EC}_{\mathrm{iw}}$ and LF can affect intrinsic WUE for hot pepper.

Stable carbon isotope composition $\left(\delta^{13} \mathrm{C}\right)$, which is frequently expressed as carbon isotope discrimination $\left(\Delta^{13} \mathrm{C}\right)$, has been correlated with gas exchange responses in the plant growth cycle. $\delta^{13} \mathrm{C}$ in plants therefore provides a time-integrated measurement of intrinsic WUE to environmental stress, such as water and salinity stresses [16, 23]. Consequently, the variation of $\Delta^{13} C$ has been suggested as an indicator of intrinsic WUE since there is a negative relationship between leaf $\Delta^{13} \mathrm{C}$ and intrinsic WUE [15, 24].

Crop nitrogen $(\mathrm{N})$ is important for plant growth. The natural variation of the $\mathrm{N}$ isotope composition $\left(\delta^{15} \mathrm{~N}\right)$ in plants under salinity stress is useful as it is related to $\mathrm{N}$ metabolism [23]. Isotope fractionation may occur during the $\mathrm{N}$ enzymatic assimilation of nitrate, recycling, translocation, exudation, or volatilization [25, 26]. Salinity-induced impacts on metabolism may cause a substantial change in the isotopic content of metabolites. For instance, increased salinity results in a significant reduction of $\delta^{15} \mathrm{~N}$ in wheat shoots, which may result from reduction in the loss of ammonia and nitrous oxide [27]. Many studies have also shown that $\delta^{15} \mathrm{~N}$ in plants can be used as an indicator to assess the mineralization rate of soil organic $\mathrm{N}$ [28]. Higher $\delta^{15} \mathrm{~N}$ in plants indicates more $\mathrm{N}$ is absorbed from soil organic $\mathrm{N}$ pools than from inorganic mineral $\mathrm{N}$. In addition, the uptake and assimilation of ammonium, plant growth and root length density or surface area may also affect plant $\mathrm{N}$ accumulation. Previous studies showed that increasing salinity leads to a reduction in the $\mathrm{N}$ content and total $\mathrm{N}$ accumulation $[23,27,29,30]$. However, the modification effect of LF on the uptake of hot pepper $\mathrm{N}$ uptake to $\mathrm{EC}_{\mathrm{iw}}$ remains unclear. In addition, the salinity-induced reduction in hot pepper $\mathrm{N}$ may affect $\mathrm{C}$ retention in the plant.

Therefore, the objectives of this study are (1) to analysis the response of photosynthetic capacity, intrinsic WUE and total $\mathrm{C}$ and $\mathrm{N}$ accumulation of hot pepper leaves exposed to different $\mathrm{EC}_{\mathrm{iw}}$ treatments, and (2) to assess the modification effect of LF on leaf gas exchange, intrinsic WUE, and total $\mathrm{C}$ and $\mathrm{N}$ accumulation to $\mathrm{EC}_{\mathrm{iw}}$.

\section{Results}

Gas exchange, intrinsic WUE, photosynthetic lightresponse and $\mathrm{CO}_{2}$-response curves

Higher $\mathrm{EC}_{\mathrm{iw}}$ induced the lower $P_{n}$ and $g_{s}$. Compared to the $\mathrm{EC}_{\mathrm{iw}}$ of $0.9 \mathrm{dS} \mathrm{m}{ }^{-1}$, the treatment with $\mathrm{EC}_{\mathrm{iw}}$ of $7.0 \mathrm{dS} \mathrm{m} \mathrm{m}^{-1}$ decreased $P_{n}$ and $g_{s}$ by 37.7 and $60.5 \%$, respectively, showing that $P_{n}$ declined slower than $g_{s}$, which led to a higher intrinsic WUE (i.e. $P_{n} / g_{s}$ ) with higher $\mathrm{EC}_{\mathrm{iw}}$ (Table 1). Interestingly, high LF did not affect $P_{n}$ and $g_{s}$ significantly. As a consequence, the intrinsic

Table 1 Photosynsthis $\left(P_{n}, \mu \mathrm{mol} \mathrm{m}^{-2} \mathrm{~s}^{-1}\right)$, leaf stomatal conductance $\left(g_{\mathrm{s}}\right.$, mol $\left.\mathrm{m}^{-2} \mathrm{~s}^{-1}\right)$, intercellular to ambient $\mathrm{CO}_{2}$ concentration ratio $\left(C_{i} / C_{a}\right)$ and intrinsic water use efficiency (WUE) ( $\mu \mathrm{mol} \mathrm{CO}_{2} \mathrm{~mol}^{-1} \mathrm{H}_{2} \mathrm{O}$ ) in hot pepper leaves subjected to varying levels of irrigation water salinity $\left(\mathrm{EC}_{\mathrm{iw}}, \mathrm{dS} \mathrm{m}^{-1}\right)$ and two leaching fractions (LF). The gas exchange parameters were measured with a fixed PPFD level of $1200 \mu \mathrm{mol} \mathrm{m} \mathrm{m}^{-2} \mathrm{~s}^{-1}$ (under light saturate condition). The values for each treatment were the averages of three measurements $(23,39$ and 76 days after transplanting) with three to six replications for each measurement

\begin{tabular}{cllll}
\hline Factors & $P_{n}$ & $g_{s}$ & $C_{i} / C_{a}$ & Intrinsic WUE \\
\hline EC $_{\text {iw }}$ & & & & \\
0.9 & $21.2 \mathrm{a}$ & $0.81 \mathrm{a}$ & $0.80 \mathrm{a}$ & $32.6 \mathrm{c}$ \\
4.7 & $16.0 \mathrm{~b}$ & $0.41 \mathrm{~b}$ & $0.74 \mathrm{~b}$ & $48.8 \mathrm{~b}$ \\
7.0 & $13.2 \mathrm{c}$ & $0.32 \mathrm{c}$ & $0.70 \mathrm{c}$ & $58.4 \mathrm{a}$ \\
$\mathrm{LF}$ & & & & \\
0.17 & 16.9 & 0.51 & 0.75 & 45.5 \\
0.29 & 17.5 & 0.56 & 0.75 & 45.4 \\
ANOVA & & & & \\
LF & NS & NS & NS & NS \\
EC & $* * *$ & $* * *$ & $* *$ & $* *$ \\
LF $\times$ EC $_{\text {iw }}$ & $*$ & NS & $*$ & $*$ \\
\hline
\end{tabular}

* and *** represent significant differences between means at 0.05 and 0.001 level of probability, respectively; NS, no significant. Different letters within a column indicate significant difference at $P<0.05$ by Duncan's multiple range tests 
WUE had no statistical difference between the two LFs treatments (Table 1). There were significant relationships (i.e., a typical logarithmic correlation) between $P_{n}$ and $g_{s}$ under different $\mathrm{EC}_{\mathrm{iw}}$ levels and $\mathrm{LF}$ treatments (Fig. 1a, b), showing that partial stomatal closure would result in an increase in intrinsic WUE [31]. A clear logarithmic decrease of intrinsic WUE with increasing of $g_{s}$ was also found based on the pooled data from all treatments (Fig. 1c). Collectively, based on these results, it is

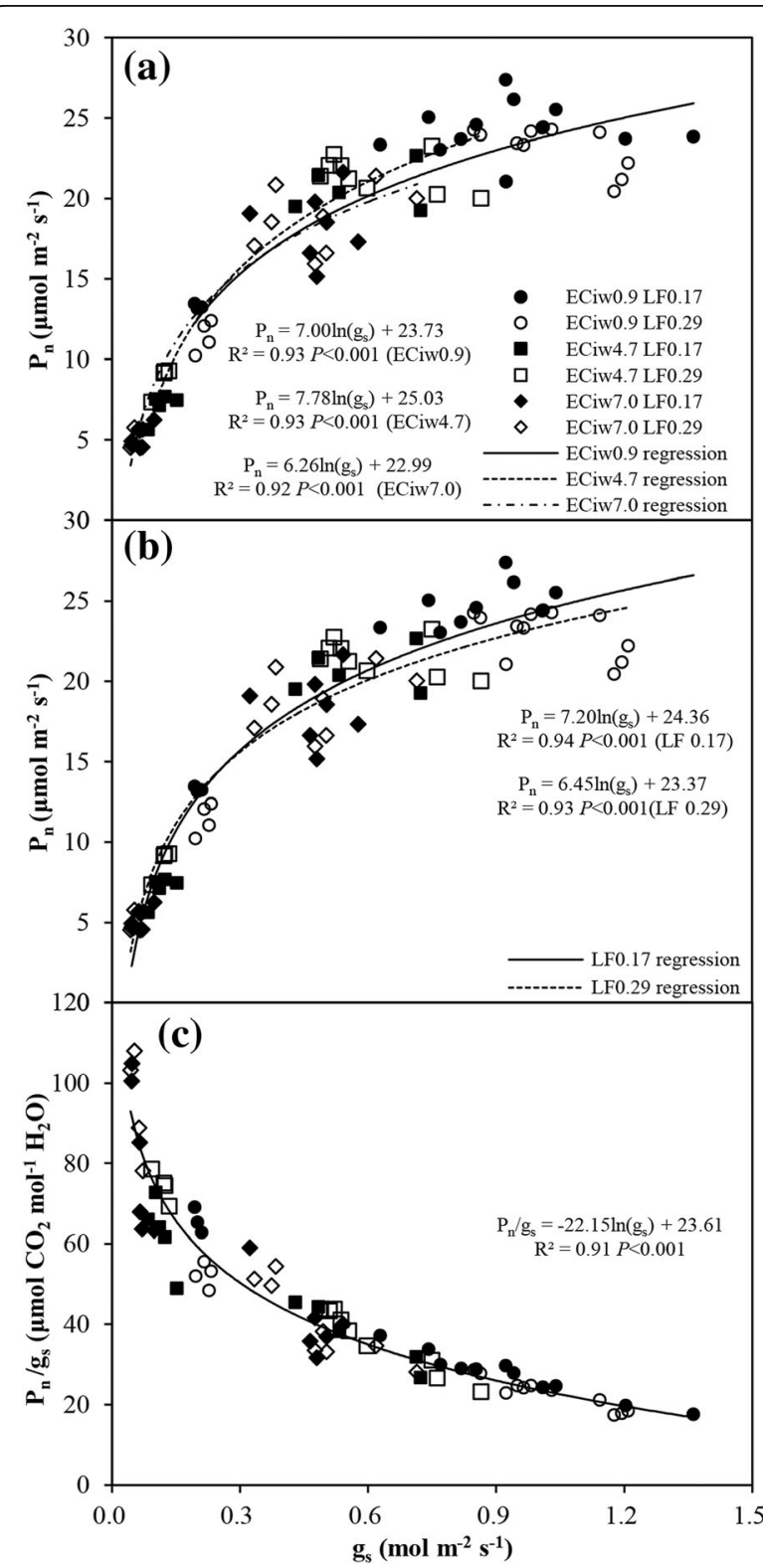

Fig. 1 Photosynthesis $\left(P_{n}\right)$ and intrinsic water use efficiency (i.e. $\left.P_{n} / g_{s}\right)$ (c) expressed as a function of stomatal conductance $\left(g_{5}\right)$ in the leaves of hot pepper plants under different levels of irrigation water salinity $\left(E C_{i w}, \mathbf{a}\right)$ and two leaching fractions $(L F, \mathbf{b})$. The data points used were obtained from the pooled data of three measurements of leaf gas exchange (23, 39 and 76 days after transplanting) suggested that $\mathrm{EC}_{\mathrm{iw}}$ reduced $g_{s}$ more than $P_{n}$, resulting in an increase in intrinsic WUE; in contrast LF had no marked effect on $g_{s}$ and $P_{n}$, leading to an identical intrinsic WUE. ANCOVA analyses also show that the $\mathrm{EC}_{\mathrm{iw}} \times g_{s}$ or $\mathrm{LF} \times g_{s}$ interactions were not significant, indicating that the slopes of the regression lines between $P_{n}$ and $g_{s}$ under different levels of $\mathrm{EC}_{\mathrm{iw}}$ and LFs were not significantly different. These results also further suggest that at a certain $g_{s}$, the differences in $P_{n}$ among the $\mathrm{EC}_{\mathrm{iw}}$ or LF were consistent (Fig. 1)

The effects of $\mathrm{EC}_{\mathrm{iw}}$ and $\mathrm{LF}$ on gas exchange were further investigated by measuring the photosynthetic light-response $\left(\mathrm{P}_{\mathrm{n}}-\mathrm{PPFD}\right)$ and $\mathrm{CO}_{2}-$ response $\left(\mathrm{P}_{\mathrm{n}}-\mathrm{C}_{\mathrm{i}}\right)$ curves. Figure 2 shows the $P_{n}-P P F D$ and $P_{n}-C_{i}$ curves of hot pepper leaves under varying $\mathrm{EC}_{\mathrm{iw}}$ and $\mathrm{LF}$ treatments. The photosynthetic characteristics inculding $\alpha, P_{n} \max , \mathrm{K}$ and $R_{d}$ derived from $\mathrm{P}_{\mathrm{n}}-\mathrm{PPFD}$ curve and $\varepsilon, P_{n}$ sat , and $R_{p}$ derived from $\mathrm{P}_{\mathrm{n}}-\mathrm{C}_{\mathrm{i}}$ curve are shown in the Table 2. There were no significant interactions between $\mathrm{EC}_{\mathrm{iw}}$ and $\mathrm{LF}$ in terms of the parameters derived from the $\mathrm{P}_{\mathrm{n}}-\mathrm{PPFD}$ and $\mathrm{P}_{\mathrm{n}}-\mathrm{C}_{\mathrm{i}}$ curves. $\mathrm{K}$ was also not influenced by $\mathrm{EC}_{\mathrm{iw}}$ and $\mathrm{LF}$, indicating $P_{n}$ increased identically to $P_{n} \max$ as increasing PPFD. The identical $R_{d}$ under various levels of $\mathrm{EC}_{\mathrm{iw}}$ and LFs indicate steady early symptom of carbon metabolism [32]. However, salinity-induced reductions in $P_{n} \max , \alpha$ and $P_{n \text { sat }}$ were observed in this study (Table 2).

In agreement with the prior analysis for $P_{n}, g_{s}$ and intrinsic WUE in this study, the improvement of carboxylation capacity, electron transport, $P_{n \text { max }}$ and $P_{n}$ sat in the higher LF were not observed on the $P_{n}-$ PPFD and $\mathrm{P}_{\mathrm{n}}-\mathrm{C}_{\mathrm{i}}$ curves (Fig. 2, Table 2), indicating that the higher LF treatment did not enhance $g_{s}$, which ultimately affected photosynthesis capacity and intrinsic WUE.

\section{$\Delta^{13} \mathrm{C}, \delta^{15} \mathrm{~N}$ and total $\mathrm{C}$ and $\mathrm{N}$ accumulation in leaves}

Although no significant interaction between $\mathrm{EC}_{\mathrm{iw}}$ and $\mathrm{LF}$ was found for the $\Delta^{13} \mathrm{C}$ of leaves, $\Delta^{13} \mathrm{C}$ decreased by 2.4 and $6.1 \%$ in the $\mathrm{EC}_{\mathrm{iw}}$ treatments of 4.7 and $7.0 \mathrm{dS} \mathrm{m} \mathrm{m}^{-1}$, respectively, when compared to the $\mathrm{EC}_{\mathrm{iw}}$ of $0.9 \mathrm{dS} \mathrm{m} \mathrm{m}^{-1}$ (Table 3). This suggests that higher $\mathrm{EC}_{\mathrm{iw}}$ had greater stomatal closure. A significantly negative linear relationship between the $\Delta^{13} \mathrm{C}$ and electrical conductivity of soil saturated paste extract measured at the end of the experiment was observed regardless of the LF treatments (Fig. 3), indicating that soil salinity restricted $\mathrm{CO}_{2}$ diffusion in $P_{n}$ [33]. A previous study has shown that salinity-induced reductions in $\Delta{ }^{13} \mathrm{C}$ accompany decreases in $\mathrm{C}_{\mathrm{i}} / \mathrm{C}_{\mathrm{a}}$ [34]. In this study, the decline in $\Delta^{13} \mathrm{C}$ as $\mathrm{EC}_{\mathrm{iw}}$ increased from 0.9 to $7.0 \mathrm{dS} \mathrm{m}^{-1}$ corresponded to a reduction of $C_{\mathrm{i}} / \mathrm{C}_{\mathrm{a}}$ from 0.8 to 0.7 (Table 1 ). In addition, a significant positive relationship between the $\Delta^{13} \mathrm{C}$ and $\mathrm{C}_{\mathrm{i}} / \mathrm{C}_{\mathrm{a}}$ between the LF treatments was also found $\left(\mathrm{R}^{2}=0.92, n=6, P<0.01\right)$. Partial stomatal closure or higher photosynthetic capacity or a combination of both could lead to a decrease in $C_{i} / C_{a}$ 


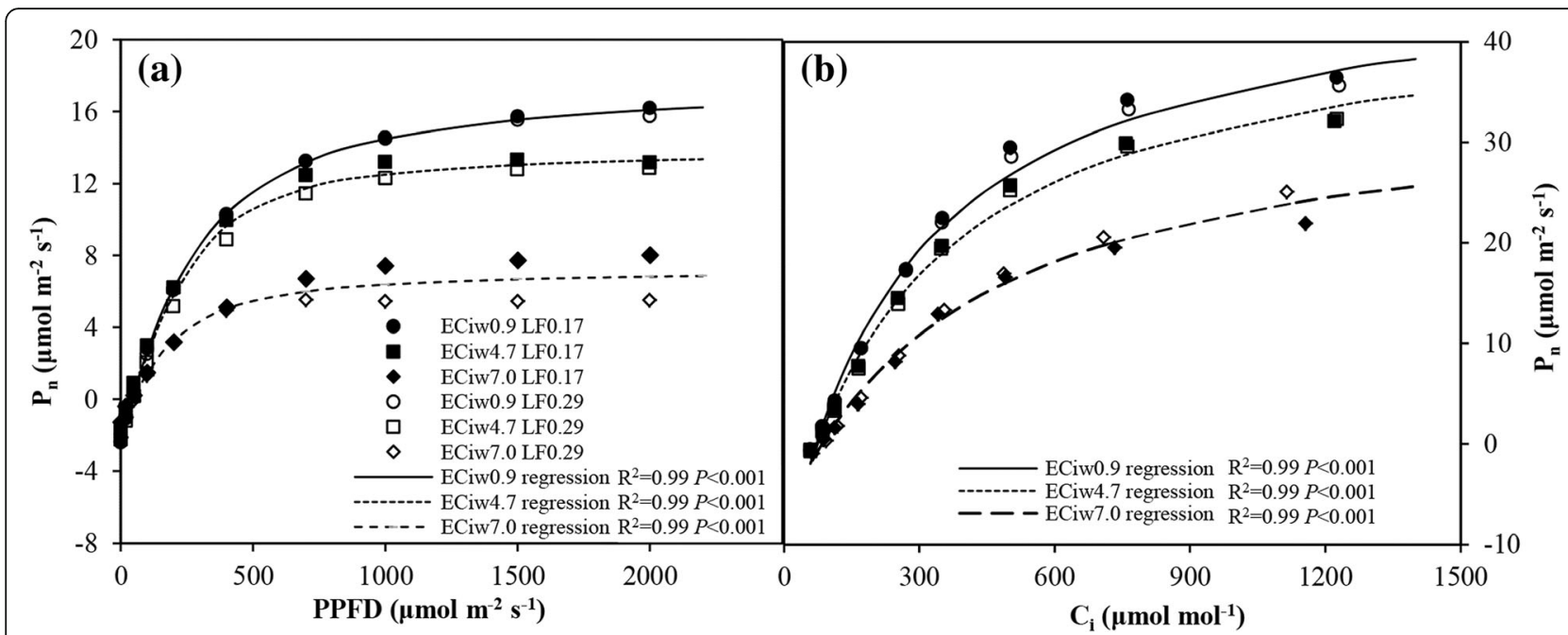

Fig. 2 Photosynthetic light-response (a) and $\mathrm{CO}_{2}$-response curves $(\mathbf{b})$ in the leaves of hot pepper plants under different levels of irrigation water salinity $\left(E_{\mathrm{iw}}\right.$ ) and leaching fractions (LF) (the measurements were made at a $\mathrm{CO}_{2}$ concentration of $400 \mathrm{\mu mol} \mathrm{mol}^{-1}$ and at a PPFD of $1200 \mu \mathrm{mol}$ $\mathrm{mol}^{-1}$, respectively for light-response curves and $\mathrm{CO}_{2}$-response curves). The three regression curves are made for the leaves of $\mathrm{EC}_{\mathrm{iw}}$ of $0.9,4.7$ and $7 \mathrm{dS}^{-1}$, respectively, across the two LFs

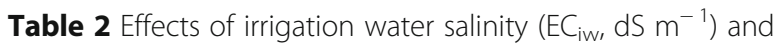
leaching fraction (LF) on maximum apparent quantum yield of $\mathrm{CO}_{2}$ ( $a$, mol CO $\mathrm{mol}^{-1}$ photons), irradiance-saturated rate of gross photosynthesis $\left(P_{n \text { max }} \mu\right.$ mol $\left.\mathrm{m}^{-2} \mathrm{~s}^{-1}\right)$, dark respiration rate $\left(R_{d}, \mu \mathrm{mol} \mathrm{CO}_{2} \mathrm{~m}^{-2} \mathrm{~s}^{-1}\right)$, and dimensionless convexity term ( $\mathrm{k}$ ) derived from the photosynthetic light-response curve and on carboxylation efficiency $\left(\varepsilon, \mathrm{mol} \mathrm{m}^{-2} \mathrm{~s}^{-1}\right)$, photosynthetic capacity $\left(P_{n \text { sat, }} \mu \mathrm{mol} \mathrm{CO}_{2} \mathrm{~m}^{-2} \mathrm{~s}^{-1}\right)$, photorespiration rate $\left(R_{p}\right.$ $\mu \mathrm{mol} \mathrm{CO}_{2} \mathrm{~m}^{-2} \mathrm{~s}^{-1}$ ) derived from the photosynthetic $\mathrm{CO}_{2}-$ response curve. The light-response curves were measured at a fixed $\mathrm{CO}_{2}$ concentration of $400 \mathrm{mmol} \mathrm{mol}^{-1}$. Measurements of $\mathrm{CO}_{2}$-response curves were conducted at a fixed PPFD of $1200 \mu \mathrm{mol} \mathrm{m} \mathrm{m}^{-2} \mathrm{~s}^{-1}$

\begin{tabular}{clllllll}
\hline Factors & $a$ & $P_{n \text { max }}$ & $k$ & $R_{d}$ & $\varepsilon$ & $P_{n \text { sat }}$ & $R_{p}$ \\
\hline EC $_{\text {iw }}$ & & & & & & & \\
0.9 & $0.052 \mathrm{a}$ & $19.9 \mathrm{a}$ & 0.53 & 2.07 & $0.224 \mathrm{a}$ & $61.0 \mathrm{a}$ & $12.7 \mathrm{a}$ \\
4.7 & $0.047 \mathrm{a}$ & $15.7 \mathrm{~b}$ & 0.78 & 1.78 & $0.188 \mathrm{a}$ & $55.7 \mathrm{a}$ & $11.2 \mathrm{a}$ \\
7.0 & $0.030 \mathrm{~b}$ & $8.6 \mathrm{c}$ & 0.83 & 1.43 & $0.109 \mathrm{~b}$ & $42.8 \mathrm{~b}$ & $7.5 \mathrm{~b}$ \\
$\mathrm{LF}$ & & & & & & & \\
0.17 & 0.045 & 16.4 & 0.64 & 1.68 & 0.179 & 52.1 & 10.5 \\
0.29 & 0.042 & 14.2 & 0.75 & 1.96 & 0.168 & 54.2 & 10.4 \\
ANOVA & & & & & & & \\
LF & NS & NS & NS & NS & NS & NS & NS \\
EC & $*$ & $* * *$ & NS & NS & $* * *$ & $*$ & $*$ \\
LF $\times$ EC $_{\text {iw }}$ & NS & NS & NS & NS & NS & NS & NS
\end{tabular}

${ }^{*}, * *$ and ${ }^{* * *}$ represent significant differences between means at 0.05, 0.01 and 0.001 level of probability, respectively; NS, no significant. Different letters within a column indicate significant difference at $P<0.05$ by Duncan's multiple range tests
[35]. In this study, a significantly positive relationship between $\mathrm{C}_{\mathrm{i}} / \mathrm{C}_{\mathrm{a}}$ and $g_{s}$ represents partial stomatal closure caused by salinity as a result of lower $C_{i} / C_{a}$ levels (Fig. 4, Table 1)

Previous studies have shown that salinity markedly reduced the $\delta^{15} \mathrm{~N}$ in leaves of broccoli and barley plants $[36,37]$. However, the $\delta^{15} \mathrm{~N}$ in leaves of hot pepper plants was not affect by $\mathrm{EC}_{\mathrm{iw}}$ (Table 3), indicating that the similar soil organic $\mathrm{N}$ mineralization and therefore the identical soil $\mathrm{N}$ bioavailability under different levels of $\mathrm{EC}_{\mathrm{iw}}$ [16]. However, total $\mathrm{C}$ and $\mathrm{N}$ accumulation in leaves decreased with increasing $\mathrm{EC}_{\mathrm{iw}}$ (Table 3).

It should be noteworthy that LF did not affect $\Delta^{13} \mathrm{C}$ with values ranging from $22.87 \%$ to $23.09 \%$. Additionally, in accordance with similar $\Delta^{13} \mathrm{C}$ values in two LF treatments, the $C_{i} / C_{a}$ was also identical for two LFs, which may attribute to slimiar stomatal opening and photosynthetic capacity as discussed earlier (Tables 1 and 2). Furthermore, LF also did not influence the $\delta^{15} \mathrm{~N}$ in leaves of hot pepper plants. However, higher LF enhanced total $C$ and $\mathrm{N}$ accumulation in leaves (Table 3 ).

\section{Discussion}

Pepper is considerate moderately sensitive to salinity (generally no yield loss when $\mathrm{EC}_{\mathrm{iw}}$ was lower than 1.5$\left.2.0 \mathrm{dS} \mathrm{m}^{-1}[14,38]\right)$. Hence higher $\mathrm{EC}_{\mathrm{iw}}$ in this study markedly inhibited the $P_{n}$ and $g_{s}$, leading to a higher intrinsic WUE. In addition, a significant linear positive correlation between intrinsic WUE and $\mathrm{EC}_{\mathrm{iw}}$ was observed within the range of $\mathrm{EC}_{\mathrm{iw}}$ levels considered here regardless of LF treatments $\left(\mathrm{R}^{2}=0.993, n=6, P<0.001\right)$. However, additional data on more severe $\mathrm{EC}_{\mathrm{iw}}$ levels are necessary to assess the aforementioned correlation. For instance, when 
Table 3 Carbon isotope discriminaion $\left(\Delta^{13} \mathrm{C}, \%\right.$ ), C content (\% DW), total $\mathrm{C}$ accumulation (g plant ${ }^{-1}$ ), nitrogen isotope composition $\left(\delta^{15} \mathrm{~N}, \%\right.$ ) and total $\mathrm{N}$ accumulation ( $\mathrm{g}$ plant $\left.{ }^{-1}\right)$ in hot pepper leaves as affected by varying levels of irrigation water salinity (EC $\mathrm{Ew}_{\mathrm{i}}$ $\mathrm{dS} \mathrm{m}^{-1}$ ) and two leaching fractions (LF). The values for each treatment measured at the end of the experiment were the averages of four replications

\begin{tabular}{|c|c|c|c|c|c|}
\hline Factors & $\Delta^{13} \mathrm{C}$ & C content & Total $\mathrm{C}$ accumulation & $\delta^{15} \mathrm{~N}$ & $\overline{\text { Total } N \text { accumulation }}$ \\
\hline \multicolumn{6}{|l|}{$\overline{E C_{i w}}$} \\
\hline 0.9 & $23.61 a$ & $40.14 a$ & $5.76 a$ & 2.44 & $0.606 a$ \\
\hline 4.7 & $23.04 b$ & $38.54 a$ & $3.80 \mathrm{~b}$ & 2.68 & $0.379 b$ \\
\hline 7.0 & $22.17 c$ & $35.43 b$ & $2.36 \mathrm{c}$ & 2.82 & $0.238 c$ \\
\hline \multicolumn{6}{|l|}{ LF } \\
\hline 0.17 & 22.87 & $36.71 b$ & $3.58 b$ & 2.69 & $0.382 b$ \\
\hline 0.29 & 23.09 & $39.72 a$ & $4.56 a$ & 2.58 & $0.435 a$ \\
\hline \multicolumn{6}{|l|}{ ANOVA } \\
\hline LF & NS & $* *$ & $* *$ & NS & * \\
\hline $\mathrm{EC}_{\mathrm{iw}}$ & $* * *$ & $* * *$ & $* * *$ & NS & $* * *$ \\
\hline $\mathrm{LF} \times \mathrm{EC}_{\mathrm{iw}}$ & NS & NS & NS & NS & NS \\
\hline
\end{tabular}

$*, * *$ and ${ }^{* * *}$ represent significant differences between means at $0.05,0.01$ and 0.001 level of probability, respectively; NS, no significant. Different letters within a column indicate significant difference at $P<0.05$ by Duncan's multiple range tests

recalculating data in Table 4 from Chartzoulakis and Klapaki (2000) [6], only a small increase in intrinsic WUE was found when $\mathrm{EC}_{\mathrm{iw}}$ higher than $12.6 \mathrm{dS} \mathrm{m} \mathrm{m}^{-1}$, showing that intrinsic WUE did not appreciably increase for the aforementioned correlation.

Salinity-induced reductions in $P_{n \text { max }}$ and $\alpha$ from $\mathrm{P}_{\mathrm{n}}-$ PPFD curves were observed in this study, revealing a comparatively lower capacity of the biochemical reactions responsible for $\mathrm{CO}_{2}$ fixation and lower photochemical efficiency of photosystem in hot pepper leaves in higher $\mathrm{EC}_{\mathrm{iw}}$ [39]. Similarly, $P_{n \text { sat }}$ derived from $\mathrm{P}_{\mathrm{n}}-\mathrm{C}_{\mathrm{i}}$ curves also restricted in the $\mathrm{EC}_{\mathrm{iw}}$ of $7.0 \mathrm{dS} \mathrm{m} \mathrm{m}^{-1}$ treatment as shown by the decline in the initial slope and the level of the upper

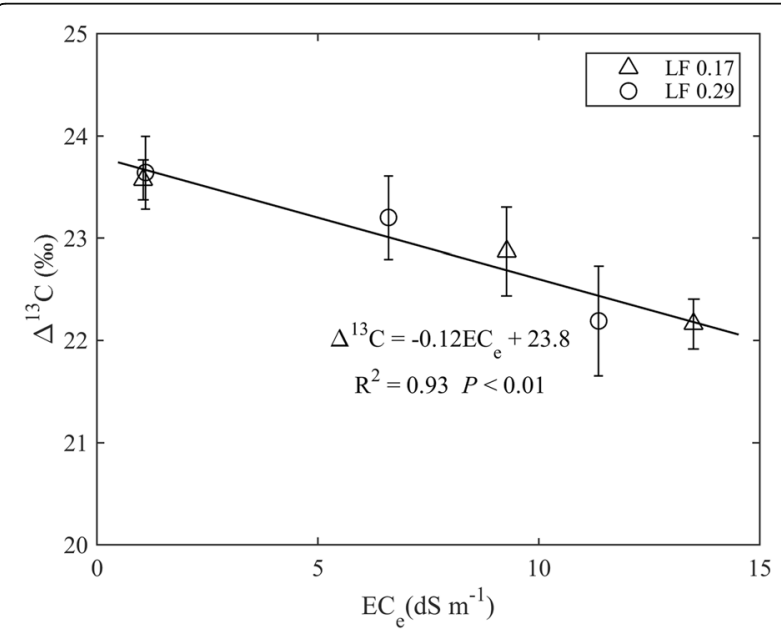

Fig. 3 Relationship between carbon isotope discrimination $\left(\Delta^{13} \mathrm{C}\right)$ and electrical conductivity of soil saturated paste extract $\left(E C_{e}\right)$ regardless of leaching fractions $(L F)$. Values are the means $\pm \operatorname{SE}(n=4)$ plateau in the $P_{n}-C_{i}$ curve (Fig. 2b) [40]. Brugnoli and Lauteri (1991) [41] observed similar results in bean and cotton plants, with the effect more marked in bean plants. A decline in carboxylation efficiency $(\varepsilon)$ was a major component among those inhibiting $P_{n}$ by mesophyll limitations in higher salinity (e.g. $\mathrm{EC}_{\mathrm{iw}}$ of $7.0 \mathrm{dS} \mathrm{m}^{-1}$ in this study); this was likely produced by a reduction in enzyme activities in the carbon reduction cycle [42]. In addition, owing to the decreases in the $\mathrm{CO}_{2} / \mathrm{O}_{2}$ ratio in the mesophyll, an increase in salinity may increase the rate of photorespiration $\left(R_{p}\right)$ in $C_{3}$ plants $[8,43]$. However, analysis of the $P_{n}-C_{i}$ curves of hot pepper leaves in this study suggested that $R_{p}$ decreased significantly when $\mathrm{EC}_{\mathrm{iw}}$ was higher than $4.7 \mathrm{dS} \mathrm{m} \mathrm{m}^{-1}$

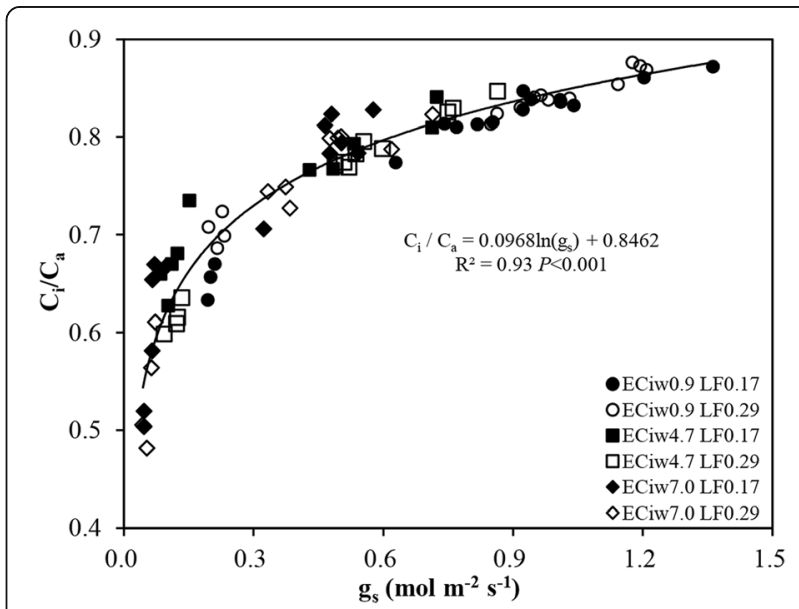

Fig. 4 Logarithmic correlation between the intercellular to ambient $\mathrm{CO}_{2}$ concentration ratio $\left(\mathrm{C}_{\mathrm{i}} / \mathrm{C}_{\mathrm{a}}\right)$ and stomatal conductance $\left(g_{\mathrm{s}}\right)$ across the two leaching fractions (LF). The data points used were from the pooled data of three measurements of gas exchange (23, 39 and 76 days after transplanting) 
Table 4 Dry biomasses of leaves and roots $\left(\mathrm{g} \mathrm{plant}^{-1}\right)$ and $\mathrm{Na}^{+}$ content ( $\mathrm{mg} \mathrm{g}^{-1} \mathrm{DW}$ ) in hot pepper leaves measured at the end of the experiment subjected to varying levels of irrigation water salinity ( $E C_{i w}, \mathrm{dS} \mathrm{m}^{-1}$ ) and two leaching fractions (LF). Mean values were calculated from four replications

\begin{tabular}{clll}
\hline Factors & Dry biomass of leaves & Dry biomass of roots & $\mathrm{Na}^{+}$content \\
\hline $\mathrm{EC}_{\text {iw }}$ & & & \\
0.9 & $14.3 \mathrm{a}$ & $5.5 \mathrm{a}$ & $2.73 \mathrm{c}$ \\
4.7 & $9.8 \mathrm{~b}$ & $3.4 \mathrm{~b}$ & $8.53 \mathrm{~b}$ \\
7.0 & $7.0 \mathrm{c}$ & $2.5 \mathrm{c}$ & $12.60 \mathrm{a}$ \\
$\mathrm{LF}$ & & & \\
0.17 & $9.6 \mathrm{~b}$ & 3.6 & $8.51 \mathrm{a}$ \\
0.29 & $11.1 \mathrm{a}$ & 4.1 & $7.39 \mathrm{~b}$ \\
ANOVA & & & $*$ \\
LF & $*$ & $\mathrm{NS}$ & $* * *$ \\
EC & $* * *$ & $* * *$ & $\mathrm{NS}$ \\
LF $\times$ EC $_{\text {iw }}$ & NS & $* *$ & $* 0.01 \mathrm{nd}$
\end{tabular}

${ }^{*}, * *$ and ${ }^{* * *}$ represent significant differences between means at 0.05, 0.01 and 0.001 level of probability, respectively; NS, no significant. Different letters within a column indicate significant difference at $P<0.05$ by Duncan's multiple range tests

(Table 2). Similar findings have also been reported in mallow [44] and mangrove [45] leaves based on the measurements of gas exchange. The enhanced PEPCase may account for the reduction in $R_{p}$ [45], however further research is needed to explore the physiological mechanisms of reduced $R_{p}$ within hot pepper leaves under high salinity levels.

It is well established that $\Delta^{13} \mathrm{C}$ analysis in leaf samples is one of the most versatile methodologies in assessing the environmental effects on the efficiency of photosynthesis in plants [32]. For instance, variation of $\Delta^{13} \mathrm{C}$ was found when plants were subjected to water and salinity stresses $[33,46]$, which was confirmed by salinity stress in this study. Variation in $\Delta^{13} \mathrm{C}$ relies not only on changes within $C_{i} / C_{a}$, but also the variation in intrinsic WUE [26]. This is confirmed by the negative correlation between the intrinsic WUE and $\Delta^{13} \mathrm{C}$ regardless of LF treatments in this study $\left(\mathrm{R}^{2}=0.92, n=6, P<0.01\right)$.

LF did not affect the gas exchange, photosynthesis capacity and hence intrinsic WUE, which further confirmed by the identical value of $\Delta^{13} \mathrm{C}$. The possible reason is that no creditable soil salinity may leach from root zone in high LF in this study, as indicated by that the electrical conductivites of soil saturated paste extract measured at the end of the experiment were no more than $2.5 \mathrm{dS} \mathrm{m}^{-1}$ between two LFs, especially for lower salinity levels [47].

Higher $\mathrm{EC}_{\mathrm{iw}}$ induced lower total $\mathrm{C}$ accumulation in leaves (Table 3). A lower leaf biomass or a decreased $C$ content in the biomass could retain less $C$ in plant [48]. In this study, lower leaf dry biomass and $\mathrm{C}$ content might account for lower total $\mathrm{C}$ accumulation in leaves in the higher $\mathrm{EC}_{\mathrm{iw}}$ treatments (Tables 3 and 4). It is noteworthy that the reduction in leaf dry biomass in higher $\mathrm{EC}_{\mathrm{iw}}$ levels could result from lower $P_{n}$ sat and limited root water uptake ability (Table 2 ). Root water uptake is mainly depended on soil's matric and osmotic potentials $[49,50]$. The salinity reduces the osmotic potential [51], causing the plant to spend more energy in taking up water from the soil solution, leading to a reduction in root water uptake [52, 53]. Salinity-induced reduction of root growth and excessive $\mathrm{Na}^{+}$absorption also limited the root water uptake rate (Table 4).

As expected, high LF enhanced total $\mathrm{C}$ accumulation in leaves because of high leaf dry biomass and $C$ content (Table 4), where the enhanced leaf dry biomass in high LF may result from the reduction in $\mathrm{Na}^{+}$uptake and increased osmotic potential (Table 4). However, the reasons for the reduction in $\mathrm{C}$ content in higher $\mathrm{EC}_{\mathrm{iw}}$ and lower LF treatments remain unclear. Wang et al. (2010) [48] suggested that the $C$ content in the plant is affected by the ability of $\mathrm{C}$ utilization in the plant. Plant $\mathrm{N}$ nutrition is one of the essential factors regulating $\mathrm{C}$ metabolism in plants because $\mathrm{N}$ is an important element for enzymes concerning metabolism, carbohydrate transport, and utilization in plants [54].

Based on literature surveys, at least four factors may determine plant $\mathrm{N}$ uptake from the soil. Firstly, the decreased leaf $\mathrm{N}$ accumulation in higher $\mathrm{EC}_{\mathrm{iw}}$ or lower LF could be attributed to a decrease in plant available $\mathrm{N}$ in the soil [28]. If this was the case, the $\delta^{15} \mathrm{~N}$ in the high $\mathrm{EC}_{\mathrm{iw}}$ or low LF treatment should be low because the source of $\mathrm{N}$ taken up by plants could be reflected by variations in $\delta^{15} \mathrm{~N}$ [55]. However, neither the $\mathrm{EC}_{\mathrm{iw}}$ nor LF affects $\delta^{15} \mathrm{~N}$ in this study (Table 3). Alternatively, the reduced leaf $\mathrm{N}$ accumulation may result from the inhibited uptake and assimilation of ammonium as a result of competitive inhibition of $\mathrm{Na}^{+}$[30]. We observed that the $\mathrm{Na}^{+}$content in roots was greater in the higher $\mathrm{EC}_{\mathrm{iw}}$ and lower LF treatments (Table 4), which might imply that the uptake and assimilation of ammonium was restricted by higher $\mathrm{Na}^{+}$in the higher $\mathrm{EC}_{\mathrm{iw}}$ and lower $\mathrm{LF}$, and reduced leaf total $\mathrm{N}$ accumulation. Thirdly, the reduction in $\mathrm{N}$ accumulation in the higher $\mathrm{EC}_{\mathrm{iw}}$ treatment may result from the decrease in the root surface area for $\mathrm{N}$ uptake [28]. Even though the root length density or surface area was not investigated in this study, the root dry biomass declined with increasing $\mathrm{EC}_{\mathrm{iw}}$ or was not affected by LF (Table 4). This might indicate the lower root density in higher $\mathrm{EC}_{\mathrm{iw}}$ and similar root density between the two LF treatments. This implies that the lower root length density and root surface area in the higher $\mathrm{EC}_{\mathrm{iw}}$ might account for the reduction in leaf $\mathrm{N}$ accumulation. Lastly, plant $\mathrm{N}$ uptake is also affected by plant growth, as shown by significant positive linear 
correlation between total $\mathrm{N}$ content and dry biomass of leaves, regardless of the LFs in this study $\left(R^{2}=0.98\right.$, $n=6, P<0.001$ ), indicating leaf total $\mathrm{N}$ accumulation was in accordance with the dry biomass accumulation of leaves.

\section{Conclusions}

In summary, our results indicated that higher salinity impacted $g_{s}$ more than $P_{n}$, which resulted in higher intrinsic WUE. High salinity also inhibited photosynthesis capacity and retained less $\mathrm{C}$ and $\mathrm{N}$ in leaves. The novelty of this study is that we found higher LF did not improve leaf gas exchange, photosynthesis capacity and intrinsic WUE. However, higher LF did enhanced $\mathrm{C}$ and $\mathrm{N}$ accumulation in leaves of hot pepper plants.

\section{Methods}

\section{Experimental design}

The experiment was conducted under a rain shelter from April 28 to July 22, 2015 at the Agro-Meteorology Research Station located in Nanjing, Jiangsu, Eastern China $\left(32.2^{\circ} \mathrm{N}, 118.7^{\circ} \mathrm{E}\right.$, altitude $\left.14.4 \mathrm{~m}\right)$. Plastic pots (top diameter $27 \mathrm{~cm}$, bottom diameter $26 \mathrm{~cm}$, and height $22 \mathrm{~cm}$ ) with holes in the bottom were used. Each pot was filled with $11 \mathrm{~kg}$ of air-dried soil (sandy loam, with sand $=75.7 \%$, silt $=20.4 \%$ and clay $=3.9 \%$ ) sieved with a $5-\mathrm{mm}$ sieve. The bulk density of soil was $1.47 \mathrm{~g} \mathrm{~cm}^{-3}$, field water capacity was $0.27 \mathrm{~cm}^{3} \mathrm{~cm}^{-3}$ and wilting point was $0.04 \mathrm{~cm}^{3} \mathrm{~cm}^{-3}$. The electrical conductivity of soil (paste) was $0.59 \mathrm{dS} \mathrm{m}^{-1}$, and the $\mathrm{pH}$ was 7.4.

One hot pepper plant (Capsicum annuum L., Bocuiwang cultivar, purchased from Jingshiyuan Co. Ltd., China) was transplanted into each pot on April 28, 2015. All the pots were saturated with tap water before the transplanting. Five days after the transplanting, each plant was irrigated using tap water with an irrigation amount of $0.9 \mathrm{~L} \mathrm{pot}^{-1}$ (all pots observed drainage). Five days after this irrigation event, three different saline water treatments were initiated for two LFs treatments.

The three $\mathrm{EC}_{\mathrm{iw}}$ levels assessed were $0.9,4.7$ and $7.0 \mathrm{dS}$ $\mathrm{m}^{-1}$ and the two LFs treatments were 0.17 and 0.29 ; each treatment was replicated four times. The 24 pots were arranged as a randomized block design. Salinity was increased by adding 1:1 m equivalent concentrations of
$\mathrm{NaCl}$ and $\mathrm{CaCl}_{2}$ to fertilizers (half strength Hoagland solution, see Heeg et al. (2008) [56] and Qiu et al. (2018) [57] for detailed composition). The fertilizers added an elec-

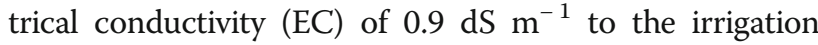
water for each treatment. The characteristics of the irrigation water for each treatment were shown in Table 5.

The evapotranspiration (ET, g) of each pot was calculated as follows:

$$
\mathrm{ET}=\mathrm{W}_{\mathrm{n}}-\mathrm{W}_{n+1}+(\mathrm{AW}-\mathrm{D}) \times \rho
$$

where $W_{n}$ and $W_{n+1}$ are the pot weights before the $n^{\text {th }}$ and $(\mathrm{n}+1)^{\text {th }}$ irrigation $(\mathrm{g})$; $\mathrm{AW}$ and D are the amounts of applied irrigation and drainage water $(\mathrm{L})$, respectively; and $\rho$ is the water bulk density $\left(1000 \mathrm{~g} \mathrm{~L}^{-1}\right)$.

At each irrigation event, the plants were irrigated with 120 and $140 \%$ of ET for each $\mathrm{EC}_{\mathrm{iw}}$ treatment, which lead to an LF of 0.17 and 0.29 according to the method proposed by Letey et al. (2011) [1]:

$$
\frac{\mathrm{AW}}{\mathrm{ET}}=\frac{1}{1-\mathrm{LF}}
$$

Therefore a different amount of water based on actual ET for each pot was applied to maintain the target LF. At the end of the experiment, the average actual LF based on the amount of seasonal drainage water and applied water was 0.17 and 0.27 , respectively [47], showing that the amount of applied irrigation water is reasonable.

The drainage water of individual pots was collected with a glass bottle positioned beneath each pot, and the amount was collected after each irrigation event. Just before each irrigation event, each pot was weighed with an electronic scale of $20 \mathrm{~kg}$ with an accuracy of $0.1 \mathrm{~g}$, afterwards the evapotranspiration and irrigation amounts were calculated. During the experimental period, the plants were irrigated every two to five days and a total of 24 irrigations were applied.

\section{Leaf gas exchange, $\delta^{13} \mathrm{C}$ and $\delta^{15} \mathrm{~N}$ of hot pepper leaves and $\mathrm{Na}^{+}$content in roots}

Leaf gas exchange parameters, including $P_{n}$ and $g_{s}$, were measured at 9:00-11:00 am on three sunny days (i.e. 23, 39 , and 76 days after transplanting) using a portable photosynthesis system with a red-blue light source (LI

Table 5 Irrigation water composition used in the experiment. The micro elements of half strength Hoagland solution (in $\mu$ mol $\mathrm{L}^{-1}$ : $40 \mathrm{Fe}-\mathrm{EDTA}, 25 \mathrm{H}_{3} \mathrm{BO}_{3}, 2.0 \mathrm{MnCl}_{2} \times 4 \mathrm{H}_{2} \mathrm{O}, 2.0 \mathrm{ZnSO}_{4} \times 7 \mathrm{H}_{2} \mathrm{O}, 0.5 \mathrm{CuSO}_{4} \times 5 \mathrm{H}_{2} \mathrm{O}, 50 \mathrm{KCl}, 0.075\left(\mathrm{NH}_{4}\right)_{6} \mathrm{Mo}_{7} \mathrm{O}_{24} \times 4 \mathrm{H}_{2} \mathrm{O}, 0.15 \mathrm{CoCl}_{2} \times$

\begin{tabular}{|c|c|c|c|c|c|c|c|c|c|c|}
\hline \multirow{2}{*}{$\begin{array}{l}E C_{i w} \\
\left(d S^{-1}\right. \\
\left.m^{-1}\right) \\
\end{array}$} & \multirow{2}{*}{$\begin{array}{l}\text { SAR } \\
(\mathrm{mmolc} \\
\left.\mathrm{L}^{-1}\right)^{0.5}\end{array}$} & \multicolumn{5}{|c|}{ Cation (mmolc L ${ }^{-1}$ ) } & \multicolumn{4}{|c|}{ Anion (mmolc $\mathrm{L}^{-1}$ ) } \\
\hline & & $\overline{\mathrm{Na}^{+}}$ & $\mathrm{Ca}^{2+}$ & $\mathrm{K}^{+}$ & $\mathrm{Mg}^{2+}$ & $\overline{\mathrm{NH}_{4}{ }^{+}}$ & $\overline{\mathrm{Cl}^{-}}$ & $\mathrm{NO}_{3}^{-}$ & $\mathrm{SO}_{4}^{2-}$ & $\mathrm{H}_{2} \mathrm{PO}_{4}^{-}$ \\
\hline 0.9 & 0.0 & 0 & 4 & 2.25 & 1 & 0.5 & 0 & 6.5 & 1 & 0.25 \\
\hline 4.7 & 5.4 & 17 & 21 & 2.25 & 1 & 0.5 & 34 & 6.5 & 1 & 0.25 \\
\hline 7.0 & 7.3 & 29 & 33 & 2.25 & 1 & 0.5 & 58 & 6.5 & 1 & 0.25 \\
\hline
\end{tabular}
$\left.6 \mathrm{H}_{2} \mathrm{O}\right)$ in irrigation water were not shown in table 
6400, LI-COR, Lincoln, NE, USA). Three to six fully grown leaves per treatment were measured with a fixed PPFD level of $1200 \mu \mathrm{mol} \mathrm{m}^{-2} \mathrm{~s}^{-1}$. The intercellular to ambient $\mathrm{CO}_{2}$ concentration ratio $\left(\mathrm{C}_{\mathrm{i}} / \mathrm{C}_{\mathrm{a}}\right)$ were also obtained from the gas exchange measurements. As noted earlier, intrinsic WUE is defined as the ratio of $P_{n}$ to $g_{s}$.

The plants were harvested on July 22, 2015. The biomasses of the leaves were dried in an oven at $70^{\circ} \mathrm{C}$ for $72 \mathrm{~h}$ to obtain constant weight. Dry leaf samples were ground and used for $\delta^{13} \mathrm{C}$ and $\delta^{15} \mathrm{~N}$ measurements. The values of $\delta^{13} \mathrm{C}$ and $\delta^{15} \mathrm{~N}$ as well as the total $\mathrm{C}$ and $\mathrm{N}$ content in the leaves were measured using a MAT253 Stable Isotope Ratio Mass Spectrometer (Thermo Fisher Scientific, USA). The $\delta^{13} \mathrm{C}$ in leaf dry biomass can be calculated as:

$$
\delta^{13} \mathrm{C}=\left(\frac{R_{\text {sample }}}{R_{\text {standard }}}-1\right) \times 1000
$$

where $R_{\text {sample }}$ and $R_{\text {standard }}$ are the ${ }^{13} \mathrm{C} /{ }^{12} \mathrm{C}$ ratio of the sample and PDB (Pee Dee Belemnite) standard, respectively.

The $\delta^{15} \mathrm{~N}$ in the leaf biomass is calculated as:

$$
\delta^{15} \mathrm{~N}=\left(\frac{R_{s}}{R_{b}}-1\right) \times 1000
$$

where $R_{s}$ and $R_{b}\left(=0.3663\right.$ at $\left.\%{ }^{15} \mathrm{~N}\right)$ are the $\mathrm{N}^{15}:\left(\mathrm{N}^{14}+\right.$ $\mathrm{N}^{15}$ ) ratios of the leaf sample to standard, respectively.

$\Delta{ }^{13} \mathrm{C}$ in leaf dry biomass can be calculated as:

$$
\Delta^{13} \mathrm{C}=\frac{\delta_{a}-\delta_{p}}{1+\delta_{p}}
$$

where $\delta_{a}$ and $\delta_{p}$ are the carbon isotope composition of source air and plant material, respectively. The $\delta_{a}$ was taken as $-8 \%$ o [34].

The roots of each plant were washed with fresh water, and dried in an oven at $70{ }^{\circ} \mathrm{C}$ to obtain constant weight. The dried roots were then ground into a powder, broken down with concentrated $\mathrm{HNO}_{3}$ that was warmed with a heating block, and finally dissolved in 5\% (v/v) highpurity $\mathrm{HNO}_{3}$. The sodium ion $\left(\mathrm{Na}^{+}\right)$content in the dry roots was determined using an Inductively Coupled Plasma-Optical Emission Spectrometry (ICP-OES, Perkin Elmer Optima 8000). The electrical conductivity of soil saturated paste extract was determined at the end of the experiment by a dual channel $\mathrm{pH} / \mathrm{mV} / \mathrm{Ion} /$ Conductivity benchtop meter (MP522, Shanghai San-Xin Instrumentation Inc., China).

\section{The $P_{n}-P P F D$ and $P_{n}-C_{i}$ curves}

The $P_{n}-$ PPFD and $P_{n}-C_{i}$ curves for different levels of $\mathrm{EC}_{\mathrm{iw}}$ and LFs were determined using a LI-6400 photosynthesis system (LI-COR, Lincoln, NE, USA). The $\mathrm{P}_{\mathrm{n}}-\mathrm{PPFD}$ curves were measured at a fixed $\mathrm{CO}_{2}$ concentration of
$400 \mu \mathrm{mol} \mathrm{mol}^{-1}$ on 2-4 plants per treatment. Measurements were made at PPFD levels of 2000, 1500, 1000, 700, $400,200,100,50,20$ and $0 \mu \mathrm{mol} \mathrm{m}^{-2} \mathrm{~s}^{-1}$. The nonrectangular hyperbola model was used to simulate $\mathrm{P}_{\mathrm{n}}$-PPFD curve [58]:

$$
P_{n}=\frac{\alpha Q+P_{n} \max -\sqrt{\left(\alpha Q+P_{n} \max \right)^{2}-4 \kappa \alpha Q P_{n} \max }}{2 \kappa}-R_{d}
$$

where $P_{n}$ is the rate of net photosynthesis $\left(\mu \mathrm{mol} \mathrm{CO}_{2}\right.$ $\left.\mathrm{m}^{-2} \mathrm{~s}^{-1}\right) ; Q$ is the PPFD $\left(\mu \mathrm{mol} \mathrm{m}{ }^{-2} \mathrm{~s}^{-1}\right) ; P_{n}$ max is the irradiance-saturated rate of gross photosynthesis $(\mu \mathrm{mol}$ $\left.\mathrm{CO}_{2} \mathrm{~m}^{-2} \mathrm{~s}^{-1}\right) ; R_{d}$ is the dark respiration rate $(\mu \mathrm{mol} \mathrm{CO}$ $\mathrm{m}^{-2} \mathrm{~s}^{-1}$ ) at $Q=0 ; \alpha$ is the maximum apparent quantum yield of $\mathrm{CO}_{2}$ (mol $\mathrm{CO}_{2} \mathrm{~mol}^{-1}$ photons); and $\mathrm{k}$ is a dimensionless convexity term $[0,1]$.

Measurements of $\mathrm{P}_{\mathrm{n}}-\mathrm{C}_{\mathrm{i}}$ curves were made at $\mathrm{CO}_{2}$ levels of 400, 250,150,100,50,500,700, 1000 and $1500 \mu \mathrm{mol} \mathrm{mol}^{-1}$ at a fixed PPFD of $1200 \mu \mathrm{mol} \mathrm{m}^{-2} \mathrm{~s}^{-1}$. The $P_{n}$ were plotted against the respective $\mathrm{C}_{\mathrm{i}}$. A nonrectangular hyperbola curve was used to simulate $P_{n}-C_{i}$ curve $[59,60]$ :

$$
P_{n}=\frac{\varepsilon P_{n \text { sat }} C_{i}}{\varepsilon C_{i}+P_{n \text { sat }}}-R_{p}
$$

where $\varepsilon$ is carboxylation efficiency $\left(\mathrm{mol} \mathrm{m}^{-2} \mathrm{~s}^{-1}\right) ; P_{n}$ sat is the photosynthetic capacity $\left(\mu \mathrm{mol} \mathrm{CO}_{2} \mathrm{~m}^{-2} \mathrm{~s}^{-1}\right)$; and $R_{p}$ is the rate of photorespiration $\left(\mu \mathrm{mol} \mathrm{CO} \mathrm{C}^{-2} \mathrm{~s}^{-1}\right)$.

\section{Statistic analysis}

Two-way analysis of variation using the general linear model-univariate procedure was performed to assess the effects of the $\mathrm{EC}_{\mathrm{iw}}$ and $\mathrm{LF}$ on gas exchange parameters, intrinsic WUE, $\Delta^{13} \mathrm{C}, \delta^{15} \mathrm{~N}, \mathrm{C}$ content and total $\mathrm{C}$ and $\mathrm{N}$ accumulation, dry biomass of leaves and roots, $\mathrm{Na}^{+}$content, the parameters obtained from the $P_{n}-$ PPFD and $\mathrm{P}_{\mathrm{n}}-\mathrm{C}_{\mathrm{i}}$ curves. All analyses were conducted in the SPSS software package (Version 21.0, IBM Corp., Armonk,

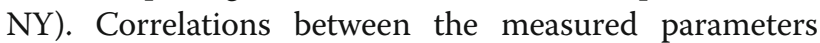
were determined with regression analyses. The slopes of the relationships between $P_{n}$ and $g_{s}$ under different $\mathrm{EC}_{\mathrm{iw}}$ levels and LFs were tested by a standard analysis of covariance (ANCOVA). $P_{n}$ was analyzed through a General Linear Model (GLM) of the natural logarithm of $g_{s}$. The $\mathrm{EC}_{\mathrm{iw}}$ (or LF) and the interaction with the linear predictor were included to test for differences in slope. If there was no significant interaction between $\mathrm{EC}_{\mathrm{iw}}$ (or LF) and linear predictor, the slopes were assumed to be the same.

\section{Abbreviations}

C: Carbon; $\mathrm{C}_{\mathrm{i}} / \mathrm{C}_{\mathrm{a}}$ : Intercellular to ambient $\mathrm{CO}_{2}$ concentration ratio; EC iw: Irrigation water salinity; $g_{s}$ : Stomatal conductance; intrinsic WUE: Intrinsic water use efficiency; LF: Leaching fraction; N: Nitrogen; 
$\mathrm{Na}^{+}$: Sodium ion; $P_{n \text { max }}$ : Irradiance-saturated rate of gross photosynthesis; $P_{n}$ sat: Photosynthetic capacity; $P_{n}$ : Net photosynthesis rate; $P_{n}{ }^{-}$

$\mathrm{C}_{\mathrm{i}}$ : photosynthetic $\mathrm{CO}_{2}$-response curve; $\mathrm{P}_{\mathrm{n}}$-PPFD: Photosynthetic lightresponse curve; $R_{\alpha}$ : Dark respiration rate; $R_{p}$ : Rate of photorespiration; a: Maximum apparent quantum yield of $\mathrm{CO}_{2} ; \delta^{13} \mathrm{C}:{ }^{13} \mathrm{C}$ isotope composition; $\Delta^{13} \mathrm{C}$ : Carbon isotope discrimination; $\delta^{15} \mathrm{~N}:{ }^{15} \mathrm{~N}$ isotope composition; $\varepsilon$ : Carboxylation efficiency; $\mathrm{K}$ : A dimensionless convexity term

\section{Acknowledgements}

We are grateful to Jinqin Xu, Jun Chen, Shanshan Cheng, Xu Liu and Hongzhou Chen for the assistance of the experiment, and to three anonymous reviewers for valuable comments.

\section{Authors' contributions}

R. Q. conducted most of the experiment, analyzed the data and wrote the manuscript. C. L., Z. W., Z. Y. and N. C. analyzed the data and improved the manuscript. F. L. provided important advice and improved the standard of English. All authors discussed the results and approved the final version of the manuscript.

\section{Funding}

We are grateful for the research grants from the National Natural Science Foundation of China (51509130, 41475107, 51779161), the Natural Science Foundation of Jiangsu Province (BK20150908), the National Science and Technology Support Program during the Twelfth Five-Year Plan (2014BAD10B07) and the Priority Academic Program Development of Jiangsu Higher Education Institutions (PAPD). The funding bodies were not involved in the design of the study and collection, analysis, and interpretation of data and in writing the manuscript.

\section{Availability of data and materials}

The datasets generated and analyzed during the current study are available from the corresponding author on reasonable request. The matlab program fitting $P_{n}-P P F D$ and $P_{n}-C_{i}$ curves using aforementioned methods in this study were shared freely in https:/github.com/shuilibite?tab=repositories.

\section{Ethics approval and consent to participate}

Not applicable.

\section{Consent for publication}

Not applicable.

\section{Competing interests}

The authors declare that they have no competing interests.

\section{Author details}

${ }^{1}$ Collaborative Innovation Center on Forecast and Evaluation of Meteorological Disasters, Jiangsu Key Laboratory of Agricultural Meteorology, Nanjing University of Information Science and Technology, Nanjing 210044 China. ${ }^{2}$ College of Agriculture, Guangxi University, Nanning 530005, Guangxi, China. ${ }^{3}$ College of Water Conservancy and Hydropower Engineering, Hohai University, Nanjing 210098, China. ${ }^{4}$ State Key Laboratory of Hydraulics and Mountain River Engineering \& College of Water Resource and Hydropower, Sichuan University, Chengdu 610065, China.

\section{Received: 9 October 2018 Accepted: 27 June 2019}

Published online: 08 July 2019

\section{References}

1. Letey J, Hoffman GJ, Hopmans JW, Grattan SR, Suarez D, Corwin DL, Oster JD, Wu L, Amrhein C. Evaluation of soil salinity leaching requirement guidelines. Agr Water Manage. 2011;98:502-6.

2. FAO-Statistics. Food and Agricultural Organization (online report): FAOSTAT Section, http://www.fao.org/faostat/en/data/QC/visualize, accessed: 2018-05-09. 2018

3. FAO. Food and Agricultural Organization (online report): Land and Water Section, http://www.fao.org/land-water/databases-and-software/cropinformation/pepper, accessed: 2018-05-09. 2018.

4. Ben-Gal A, Ityel E, Dudley L, Cohen S, Yermiyahu U, Presnov E, Zigmond L, Shani U. Effect of irrigation water salinity on transpiration and on leaching requirements: a case study for bell peppers. Agr Water Manage. 2008:95:587-97.

5. Qiu RJ, Jing YS, Liu CW, Yang ZQ, Wang ZC. Response of hot pepper yield, fruit quality, and fruit ion content to irrigation water salinity and leaching fractions. Hortscience. 2017;52:979-85.

6. Chartzoulakis K, Klapaki G. Response of two greenhouse pepper hybrids to $\mathrm{NaCl}$ salinity during different growth stages. Sci Hortic-Amsterdam. 2000;86:247-60.

7. Neto MCL, Lobo AK, Martins MO, Fontenele AV, Silveira JAG. Dissipation of excess photosynthetic energy contributes to salinity tolerance: a comparative study of salt-tolerant Ricinus communis and salt-sensitive Jatropha curcas. J Plant Physiol. 2014;171:23-30.

8. Hossain MS, Dietz K. Tuning of redox regulatory mechanisms, reactive oxygen species and redox homeostasis under salinity stress. Front Plant Sci. 2016;7:548

9. Aktas H, Abak K, Cakmak I. Genotypic variation in the response of pepper to salinity. Sci Hortic-Amsterdam. 2006:110:260-6.

10. Ben-Gal A, Beiersdorf I, Yermiyahu U, Soda N, Presnov E, Zipori I, Crisostomo RR, Dag A. Response of young bearing olive trees to irrigation-induced salinity. Irrig Sci. 2017;35:99-109.

11. Soda N, Ephrath JE, Dag A, Beiersdorf I, Presnov E, Yermiyahu U, Ben-Gal A. Root growth dynamics of olive (Olea europaea L.) affected by irrigation induced salinity. Plant Soil. 2017:411:305-18.

12. Heakal MS, Modaihsh AS, Mashhady AS, Metwally Al. Combined effects of leaching fraction, salinity, and potassium content of waters on growth and water-use efficiency of wheat and barley. Plant Soil. 1990;125:177-84.

13. Heidarpour M, Mostafazadeh Fard B, Arzani A, Aghakhani A, Feizi M. Effects of irrigation water salinity and leaching fraction on yield and evapotranspiration in spring wheat. Commun Soil Sci Plan. 2009;40:2521-35.

14. Semiz GD, Suarez DL, Ünlükara A, Yurtseven E. Interactive effects of salinity and $\mathrm{N}$ on pepper (Capsicum annuum L.) yield, water use efficiency and root zone and drainage salinity. J Plant Nutr. 2014;37:595-610.

15. Cui N, Du T, Kang S, Li F, Hu X, Wang M, Li Z. Relationship between stable carbon isotope discrimination and water use efficiency under regulated deficit irrigation of pear-jujube tree. Agr Water Manage. 2009;96:1615-22.

16. Wang YS, Janz B, Engedal T, de Neergaard A. Effect of irrigation regimes and nitrogen rates on water use efficiency and nitrogen uptake in maize. Agr Water Manage. 2017:179:271-6.

17. Gilbert ME, Zwieniecki MA, Holbrook NM. Independent variation in photosynthetic capacity and stomatal conductance leads to differences in intrinsic water use efficiency in 11 soybean genotypes before and during mild drought. J Exp Bot. 2011;62:2875-87.

18. Ewe SM, Sternberg LDSL. Growth and gas exchange responses of Brazilian pepper (Schinus terebinthifolius) and native South Florida species to salinity. Trees. 2005:19:119-28.

19. Yarami N, Sepaskhah AR. Physiological growth and gas exchange response of saffron (Crocus sativus L.) to irrigation water salinity, manure application and planting method. Agr Water Manage. 2015;154:43-51.

20. Colla G, Roupahel Y, Cardarelli M, Rea E. Effect of salinity on yield, fruit quality, leaf gas exchange, and mineral composition of grafted watermelon plants. Hortscience. 2006:41:622-7.

21. Fernández-García N, Olmos E, Bardisi E, García-De La Garma J, LópezBerenguer C, Rubio-Asensio JS. Intrinsic water use efficiency controls the adaptation to high salinity in a semi-arid adapted plant, henna (Lawsonia inermis L.). J Plant Physiol. 2014;171:64-75.

22. Koyro H. Effect of salinity on growth, photosynthesis, water relations and solute composition of the potential cash crop halophyte Plantago coronopus (L.). Environ Exp Bot. 2006;56:136-46.

23. Yousfi S, Serret MD, Márquez AJ, Voltas J, Araus JL. Combined use of $\delta^{13} \mathrm{C}$ $\delta^{18} \mathrm{O}$ and $\delta^{15} \mathrm{~N}$ tracks nitrogen metabolism and genotypic adaptation of durum wheat to salinity and water deficit. New Phytol. 2012;194:230-44.

24. Wei ZH, Du TS, Zhang J, Xu SJ, Cambre PJ, Davies WJ. Carbon isotope discrimination shows a higher water use efficiency under alternate partial root-zone irrigation of field-grown tomato. Agr Water Manage. 2016;165:33-43

25. Tcherkez G. Natural ${ }^{15} \mathrm{~N} /{ }^{14} \mathrm{~N}$ isotope composition in $\mathrm{C}_{3}$ leaves: are enzymatic isotope effects informative for predicting the ${ }^{15} \mathrm{~N}$-abundance in key metabolites? Funct Plant Biol. 2011:38:1-12.

26. Yousfi S, Serret MD, Araus JL. Comparative response of $\delta^{13} \mathrm{C}, \delta^{18} \mathrm{O}$ and $\delta^{15} \mathrm{~N}$ in durum wheat exposed to salinity at the vegetative and reproductive stages. Plant Cell Environ. 2013;36:1214-27. 
27. Yousfi S, Serret MD, Voltas J, Araus JL. Effect of salinity and water stress during the reproductive stage on growth, ion concentrations, $\Delta^{13} \mathrm{C}$, and $\delta^{15} \mathrm{~N}$ of durum wheat and related amphiploids. J Exp Bot. 2010;61:3529-42.

28. Wang ZC, Liu FL, Kang SZ, Jensen CR. Alternate partial root-zone drying irrigation improves nitrogen nutrition in maize (Zea mays L.) leaves. Environ Exp Bot. 2012;75:36-40.

29. Shaheen R, Hood Nowotny RC. Carbon isotope discrimination: potential for screening salinity tolerance in rice at the seedling stage using hydroponics. Plant Breed. 2005;124:220-4.

30. Jampeetong $\mathrm{A}$, Brix $\mathrm{H}$. Effects of $\mathrm{NaCl}$ salinity on growth, morphology, photosynthesis and proline accumulation of Salvinia natans. Aquat Bot. 2009;91:181-6.

31. Liu F, Shahnazari A, Andersen MN, Jacobsen S, Jensen CR. Physiological responses of potato (Solanum tuberosum L.) to partial root-zone drying: ABA signalling, leaf gas exchange, and water use efficiency. J Exp Bot. 2006:57:3727-35.

32. Wang ZC, Kang SZ, Jensen CR, Liu FL. Alternate partial root-zone irrigation reduces bundle-sheath cell leakage to $\mathrm{CO}_{2}$ and enhances photosynthetic capacity in maize leaves. J Exp Bot. 2011;63:1145-53.

33. Choi W, Ro H, Chang SX. Carbon isotope composition of Phragmites australis in a constructed saline wetland. Aquat Bot. 2005;82:27-38.

34. Farquhar GD, Ehleringer JR, Hubick KT. Carbon isotope discrimination and photosynthesis. Annu Rev Plant Biol. 1989:40:503-37.

35. Condon AG, Richards RA, Rebetzke GJ, Farquhar GD. Improving intrinsic water-use efficiency and crop yield. Crop Sci. 2002;42:122-31.

36. Amor FMD, Cuadra-Crespo P. Alleviation of salinity stress in broccoli using foliar urea or methyl-jasmonate: analysis of growth, gas exchange, and isotope composition. Plant Growth Regul. 2011;63:55-62.

37. Pérez-López U, Robredo A, Miranda-Apodaca J, Lacuesta M, Muñoz-Rueda A, Mena-Petite A. Carbon dioxide enrichment moderates salinity-induced effects on nitrogen acquisition and assimilation and their impact on growth in barley plants. Environ Exp Bot. 2013:87:148-58.

38. Maas EV, Hoffman GJ. Crop salt tolerance-current assessment. J Irrig Drain Div. 1977:103:115-34

39. Suárez $\mathrm{N}$, Medina E. Influence of salinity on $\mathrm{Na}^{+}$and $\mathrm{K}^{+}$accumulation, and gas exchange in Avicennia germinans. Photosynthetica. 2006:44:268-74.

40. Ball MC, Farquhar GD. Photosynthetic and stomatal responses of two mangrove species, Aegiceras corniculatum and Avicennia marina, to long term salinity and humidity conditions. Plant Physiol. 1984;74:1-6.

41. Brugnoli $E$, Lauteri M. Effects of salinity on stomatal conductance, photosynthetic capacity, and carbon isotope discrimination of salt-tolerant (Gossypium hirsutum L.) and salt-sensitive (Phaseolus vulgaris L.) $C_{3}$ nonhalophytes. Plant Physiol. 1991;95:628-35.

42. Everard JD, Gucci R, Kann SC, Flore JA, Loescher WH. Gas exchange and carbon partitioning in the leaves of celery (Apium graveolens L.) at various levels of root zone salinity. Plant Physiol. 1994;106:281-92.

43. Macler BA. Salinity effects on photosynthesis, carbon allocation, and nitrogen assimilation in the red alga, Gelidium coulteri. Plant Physiol. 1988;88:690-4.

44. Zhang Y. Study on photoprotective mechanisms under salt stress in Kosteletzkya virginica L. Presl. Jinan: Shandong Normal University; 2008.

45. Wei L. Carbon stable isotope composition in three mangrove species under salinity. Xiamen: Xiamen University; 2007.

46. Centritto M, Lauteri M, Monteverdi MC, Serraj R. Leaf gas exchange, carbon isotope discrimination, and grain yield in contrasting rice genotypes subjected to water deficits during the reproductive stage. J Exp Bot. 2009;60:2325-39.

47. Qiu RJ, Liu CW, Wang ZC, Yang ZQ, Jing YS. Effects of irrigation water salinity on evapotranspiration modified by leaching fractions in hot pepper plants. Sci Rep. 2017;7:7231.

48. Wang YS, Liu FL, Andersen MN, Jensen CR. Carbon retention in the soil-plant system under different irrigation regimes. Agr Water Manage. 2010;98:419-24

49. Bhantana P, Lazarovitch N. Evapotranspiration, crop coefficient and growth of two young pomegranate (Punica granatum L.) varieties under salt stress. Agr Water Manage. 2010;97:715-22

50. Hopmans JW, Bristow KL. Current capabilities and future needs of root water and nutrient uptake modeling. Adv Agron. 2002;77:103-83.

51. Corwin DL, Rhoades JD, Šimůnek J. Leaching requirement for soil salinity control: steady-state versus transient models. Agr Water Manage. 2007;90:165-80
52. Chen S, Zhang ZY, Wang ZC, Guo XP, Liu MH, Hamoud YA, Zheng JC, Qiu RJ. Effects of uneven vertical distribution of soil salinity under a buried straw layer on the growth, fruit yield, and fruit quality of tomato plants. Sci HorticAmsterdam. 2016;203:131-42.

53. Ramos TB, Šimůnek J, Gonçalves MC, Martins JC, Prazeres A, Pereira LS. Two-dimensional modeling of water and nitrogen fate from sweet sorghum irrigated with fresh and blended saline waters. Agr Water Manage. 2012;111:87-104.

54. Huppe HC, Turpin DH. Integration of carbon and nitrogen metabolism in plant and algal cells. Annu Rev Plant Biol. 1994;45:577-607.

55. Choi W, Lee S, Ro H, Kim K, Yoo S. Natural ${ }^{15} \mathrm{~N}$ abundances of maize and soil amended with urea and composted pig manure. Plant Soil. 2002;245:223-32

56. Heeg C, Kruse C, Jost R, Gutensohn M, Ruppert T, Wirtz M, Hell R. Analysis of the Arabidopsis O-acetylserine (thiol) lyase gene family demonstrates compartment-specific differences in the regulation of cysteine synthesis. Plant Cell. 2008;20:168-85.

57. Qiu RJ, Yang ZQ, Jing YS, Liu CW, Luo XS, Wang ZC. Effects of irrigation water salinity on the growth, gas exchange parameters, and ion concentration of hot pepper plants modified by leaching fractions. Hortscience. 2018;53:1050-5.

58. Richardson AD, Duigan SP, Berlyn GP. An evaluation of noninvasive methods to estimate foliar chlorophyll content. New Phytol. 2002;153:185-94.

59. Kyei-Boahen S, Lada R, Astatkie T, Gordon R, Caldwell C. Photosynthetic response of carrots to varying irradiances. Photosynthetica. 2003;41:301-5.

60. Ye Z. A review on modeling of responses of photosynthesis to light and $\mathrm{CO}_{2}$. Chinese J Plant Ecol. 2010;34:727-40.

\section{Publisher's Note}

Springer Nature remains neutral with regard to jurisdictional claims in published maps and institutional affiliations.
Ready to submit your research? Choose BMC and benefit from:

- fast, convenient online submission

- thorough peer review by experienced researchers in your field

- rapid publication on acceptance

- support for research data, including large and complex data types

- gold Open Access which fosters wider collaboration and increased citations

- maximum visibility for your research: over $100 \mathrm{M}$ website views per year

At BMC, research is always in progress.

Learn more biomedcentral.com/submissions 